\title{
Preparation, characterization and in vitro behavior of a new eutectoid bioceramic
}

\author{
V. Rubio ${ }^{\text {a }}$, P. Mazón ${ }^{\mathrm{b}}$, M.A. de la Casa-Lillo ${ }^{\text {a }}$, P.N. De Aza ${ }^{\text {a,* }}$ \\ ${ }^{a}$ Instituto de Bioingeniería. Universidad Miguel Hernández, Edificio Vinalopó. Avda. de la Universidad s/n. 03202- Elche, Alicante, Spain \\ ${ }^{\mathrm{b}}$ Departamento de Ciencia de Materiales, Óptica y Tecnología Electrónica. Universidad Miguel Hernández, Edificio Torrevaillo. Avda. de la Universidad s/n. \\ 03202- Elche, Alicante, Spain \\ Received 22 July 2014; accepted 21 August 2014
}

\begin{abstract}
A new type of bioceramic has been designed and obtained within the sub-system $\mathrm{Ca}_{2} \mathrm{SiO}_{4}-7 \mathrm{CaOP}_{2} \mathrm{O}_{5} 2 \mathrm{SiO}_{2}$. The selected composition was that corresponding to the eutectoid point $69 \mathrm{wt} \%$ dicalcium silicate-31 wt $\%$ tricalcium phosphate. Sintering behavior, phase evolution and microstructural changes were analyzed by XRD and SEM. Bio-reactivity was determined by immersion of materials in simulated body fluid for several periods of time as well as studies in human adipose stem cells (hASC). The investigated materials are bio-acceptable since no toxic or other harmful evidence was detected. A carbonated hydroxyapatite was formed on the surface of the 31R material within 3 days. Cell attachment assay showed that the ceramics supported the hASC cells adhesion and spreading, and the cells established close contacts with the ceramics after $24 \mathrm{~h}$ of culture. The influence of the microstructure (porosity, grain size and phase composition) on the in vitro behavior of the obtained bioceramics was also examined.
\end{abstract}

(C) 2014 Elsevier Ltd. All rights reserved.

Keywords: Bioceramics; Dicalcium silicate; Bioactivity; Biocompatibility; Electron microscopy

\section{Introduction}

A series of calcium phosphate-based materials (bioglasses, glass ceramics, ceramics, cements, coatings and bioactive composites) have attracted considerable interest for orthopedic, oral and maxillofacial applications because of their biocompatibility and tight bonding to bone, resulting in the growth of healthy tissue directly onto their surface. ${ }^{1-5}$

In recent years, some $\mathrm{Si}$ and $\mathrm{Mg}$ containing ceramics have drawn interests in the development of bone implant materials. ${ }^{6-8}$ Previous research suggests that silicon, as an essential element in skeletal development. Calrisle ${ }^{9-11}$ first reported in the 1970s that silicon was uniquely localized in the active areas of young bone and involved in the early stage of bone calcification. Similar studies by Schwarz and Milne ${ }^{12}$ have shown that silicon

\footnotetext{
* Corresponding author. Tel.: +34 966658 485; fax: +34 965222033.

E-mail addresses: pmazon@umh.es (P. Mazón), mcasa@umh.es (M.A. de la Casa-Lillo),piedad@umh.es, virtudesrubiodiaz@gmail.com (P.N. De Aza).
}

deficiency in rats resulted in skull deformation, with the cranial bones appearing flatter than normal.

Dicalcium silicate $\left(\mathrm{Ca}_{2} \mathrm{SiO}_{4}\right)$ is an important material in the calcium-silica system, which is frequently identified as an important constituent in Portland cement, ${ }^{13,14}$ refractory materials ${ }^{15}$ and corrosion-resistance coating materials. ${ }^{16,17}$ And it has also been well studied because of its polymorphism. ${ }^{18}$ Recently, $\mathrm{Ca}_{2} \mathrm{SiO}_{4}$ ceramics have been investigated as a new type of bioceramic for hard tissue regeneration. ${ }^{19}$ Some studies ${ }^{20}$ have demonstrated that $\mathrm{Ca}_{2} \mathrm{SiO}_{4}$ powders, ceramics and coatings are bioactive and can quickly induce the formation of a bone-like apatite layer on their surface after soaking in a simulated body fluid (SBF). However, poor sinterability and the residual pores in $\mathrm{Ca}_{2} \mathrm{SiO}_{4}$ ceramics deteriorate the mechanical properties.

Tricalcium phosphate $\left(\mathrm{Ca}_{3}\left(\mathrm{PO}_{4}\right)_{2}=\mathrm{TCP}\right)$ is one of the most important biomaterials based on phosphates currently recognized as ceramic material that significantly simulate the mineralogical structural of bone. ${ }^{1-3}$ When TCP ceramics are implanted in vivo, they are non-toxic, antigenically 
inactive, non-carcinogenic and bond directly to bone without any intervening connective tissue later. They show good biological compatibility, safety and osteoconductivity in living tissues, such that, they are clinically used for hard tissue replacement. $^{21,22}$ The TCP has three polymorphic forms, $\beta$, $\alpha$ and $\alpha^{\prime}$. The last one lacks interest since it transforms during the cooling into the $\alpha$ form. $\beta$-TCP is stable to room temperature and reconstructive transforms to $1125^{\circ} \mathrm{C}$ into $\alpha$ TCP, which is metastably retained during the cooling until room temperature. ${ }^{23,24}$ Moreover, $\alpha$-TCP is more soluble and biodegradable than HA, and it is expected that Si ions occupying $P$ sites in TCP network are more labile than in the HA network as well. Dissolution and biodegradation rates are in the order $\alpha$-TCP $>\beta$-TCP $>\mathrm{HA}^{21}$ and they can be strongly influenced by ion substitutions. ${ }^{25-27}$

As a consequence, Si-substituted silicon-doped calcium phosphates (CaPs) have attracted the interest of many scientists because $\mathrm{Si}$ incorporation is considered to be a promising way to improve the bioactivity of CaP-based biomaterials. ${ }^{26-32}$ According to the above considerations, materials containing phosphorus, calcium and silicon are promising candidates for preparing bioceramics and glass ceramics with improved osteogenic properties.

Compositions belonging to the system dicalcium silicate $\left(\mathrm{Ca}_{2} \mathrm{SiO}_{4}=\mathrm{C}_{2} \mathrm{~S}\right)$-tricalcium phosphate $\left(\mathrm{Ca}_{3}\left(\mathrm{PO}_{4}\right)_{2}=\mathrm{TCP}\right)^{33,34}$ are promising candidates for preparing new ceramic bone implants. In this context, the objectives of this work were to fabricate novel ceramics in the sub-system $2 \mathrm{CaOSiO}_{2}$ $\left(\mathrm{C}_{2} \mathrm{~S}\right)-7 \mathrm{CaOP}_{2} \mathrm{O}_{5} 2 \mathrm{SiO}_{2}(\mathrm{~A}) .^{35}$ The effect of the microstructure (porosity, grain size and phase composition), on the in vitro behavior of the new ceramics in a simulated body fluid and human adipose stem cells attachment and proliferation has been studied.

\section{Material and methods}

\subsection{Materials and processing methods}

Chemicals used in the synthesis of tricalcium phosphate and dicalcium silicate were calcium hydrogen phosphate anhydrous $\left(\mathrm{CaHPO}_{4}>98.0 \mathrm{wt} \%\right.$, Panreac), calcium carbonate $\left(\mathrm{CaCO}_{3}>99.0 \mathrm{wt} \%\right.$ Fluka $)$ and high-purity silicon oxide $\left(\mathrm{SiO}_{2}>99.7\right.$ wt\%, Strem Chemicals). Stoichiometric quantities of the raw powders to obtain tricalcium phosphate and dicalcium silicate were ground in a laboratory mixing miller (MM301-Retsch) by using PSZ-zirconia balls. In both syntheses the powder were initially calcined at $950{ }^{\circ} \mathrm{C}$ for $4 \mathrm{~h}$ to decompose $\mathrm{CaCO}_{3}$ followed by mixing miller with PSZ-zirconia balls and isopropyl alcohol as suspension media. The powder was then dried and sieved through a 30 mesh screen.

For TCP, the powders were heated in a platinum crucible at $1500{ }^{\circ} \mathrm{C}$ for $3 \mathrm{~h}$. Then was liquid-nitrogen quenched by rapid removal from the furnace. For $\mathrm{C}_{2} \mathrm{~S}$, the powders were cold isotatically pressed at $200 \mathrm{MPa}$ and heat treated at $1525^{\circ} \mathrm{C}$ for $12 \mathrm{~h}$, at a heating rate of $8.3^{\circ} \mathrm{C} / \mathrm{min}$ followed by cooling rate of $5^{\circ} \mathrm{C} / \mathrm{min}$. The reaction-sintering temperature was selected bearing in mind the information provided by the phase equilibrium diagram $\mathrm{SiO}_{2}-\mathrm{CaO}$ evaluated and reported by Eriksson et al. ${ }^{36}$ Then the powders thus obtained were ground and characterized by X-ray diffraction (XRD-Bruker AXS D8-Advance X-ray Diffractometer (Karksruhe, Germany)) and particle size distribution in powder aqueous suspension (Laser diffraction, Mastersizer S Malvern).

A mixture of $69 \mathrm{wt} \% \mathrm{C}_{2} \mathrm{~S} / 31 \mathrm{wt} \% \mathrm{TCP}$ was prepared. First, TCP and $\mathrm{C}_{2} \mathrm{~S}$ powders were ground to an average particle size of $\sim 20 \mu \mathrm{m}$, and the desired proportions of each component were weighed in an analytical balance and thoroughly mixed with PSZ-zirconia balls. After drying, the samples were isostatically pressed in bars at $200 \mathrm{MPa}$. Pellets obtained from the bars were put into small platinum foil crucibles that were suspended from a platinum wire in the hot zone of an electrical furnace with an electronic temperature controller $\left( \pm 1^{\circ} \mathrm{C}\right)$. The pellets were heated up to $1550^{\circ} \mathrm{C}$ for a total period of $144 \mathrm{~h}$ ( 6 days), with quenching in liquid-nitrogen, milling, pressing and reheating every $24 \mathrm{~h}$.

The final step in this preparation involved two different ways of cooling. The fist one, cooling the sample from $1550^{\circ} \mathrm{C}$ inside the furnace to $512{ }^{\circ} \mathrm{C}$ and heating at $512{ }^{\circ} \mathrm{C} / 24 \mathrm{~h}$ followed by slow cooling to room temperature at a rate of $3{ }^{\circ} \mathrm{C} / \mathrm{min}$. This combined heat treatment procedure was required to ensure that the equilibrium conditions were achieved. The second material was quenched from $1550{ }^{\circ} \mathrm{C}$ in liquid nitrogen in order to obtain at room temperature as a mestastable phase the high temperature phase of the system $\mathrm{Ca}_{2} \mathrm{SiO}_{4}-\mathrm{Ca}_{3}\left(\mathrm{PO}_{4}\right)_{2}$. The heat treatment temperatures were carefully selected bearing in mind information provided by the $2 \mathrm{CaOSiO}_{2}-7 \mathrm{CaOP}_{2} \mathrm{O}_{5} 2 \mathrm{SiO}_{2}$ sub-system existing within the binary system of $\mathrm{Ca}_{3}\left(\mathrm{PO}_{4}\right)_{2}-\mathrm{Ca}_{2} \mathrm{SiO}_{4} \cdot{ }^{35}$ The final samples were cut from the bars obtained, which measured $7 \mathrm{~mm}$ in diameter and $1.5 \mathrm{~mm}$ in thickness.

\subsection{Ceramics characterization}

Next, the pellets were removed from the platinum foils, embedded in an epoxy resin under vacuum and progressively polished down to $0.1 \mu \mathrm{m}$ diamond paste and etched with acetic acid with a concentration of $0.5 \%$ for $2 \mathrm{~s}$. Then, they were gently cleaned in an ultrasonic bath with distilled water, dried and palladium coated for scanning electron microscope (SEM-Hitachi S-3500N, Ibaraki, Japan) observations. The chemical composition of crystalline grains was qualitatively determined with an energy dispersive spectroscopy (EDS-INCA-Oxford) system coupled to the above-described electron microscope.

XRD analyses were carried out to determine the crystalline phases of the different ceramics obtained. XRD patterns were obtained using $\lambda_{\mathrm{CuK} \alpha 1}$ radiation $(0.15418 \mathrm{~nm})$ and a secondary curved graphite monochromator. Data were collected in the Bragg-Brentano $(\theta / 2 \theta)$ vertical geometry (flat reflection mode) between $20^{\circ}$ and $50^{\circ}(2 \theta)$ at $0.05^{\circ}$ steps, counting 1.5 s per step. Samples were rotated at $30 \mathrm{rpm}$ during acquisition of patterns in order to improve averaging. The diffractometer optic was a system of primary Soller foils between the X-ray tube and the fixed aperture slit. One scattered radiation slit of $1 \mathrm{~mm}$ was placed after the sample, followed by a system of secondary Soller slits and a detector slit of $0.1 \mathrm{~mm}$. The X-ray tube was operated at $40 \mathrm{kV}$ 
at $30 \mathrm{~mA}$. Diffractograms of samples were compared with the database provided by the Joint Committee on Powder Diffraction Standards (JCPDS).

\subsection{Soaking in $S B F$}

In order to estimate the bioactivity of the ceramics, Kokubo et al. ${ }^{37}$ proposed in 2006 the Tris-buffered SBF, with an ion concentration nearly equal to that of human blood plasma. The ceramic disks were placed in polystyrene bottles containing $50 \mathrm{ml}$ of $\mathrm{SBF}$ at $\mathrm{pH}=7.40$. The solid/liquid weight ratio was equal to $5 \times 10^{-3}$. The bottles with $\mathrm{SBF}$ and samples were incubated at $37 \pm 0.5^{\circ} \mathrm{C}$ in a shaking water bath for predetermined intervals. After different soaking periods (up to 14 days) the disks were removed from SBF, rinsed with deionized water, and dried at room temperature.

The samples surfaces and the cross-sections, after the exposure to the SBF, were examined at $20 \mathrm{keV}$. The cross-sections were previously polished to $1 \mu \mathrm{m}$ finish, using diamond paste, gently cleaned, in an ultrasonic bath, and palladium coated for SEM examination and microanalysis by EDS. The samples evolution was established by measuring the thickness of the layer formed in the ceramic-SBF interface by SEM.

The SBF was removed after several periods of immersion and silicon, calcium and phosphorus were determined in the removed SBF by inductively coupled plasma optical emission spectrometry (ICP-OES Perkin-Elmer Optima $2000^{\mathrm{TM}}$ ). For TEM study the samples were prepared by careful removal of the reaction layer from sample surfaces using a razor blade, and dispersing the powder on the surface of ethanol in a Petri dish. The powder specimens after drying were then collected on carbon coated TEM copper grids of 300 mesh. Electron beam transparent particles were chosen for TEM examination by selected area diffraction (SAD) and also EDS.

\subsection{Cell adhesion and proliferation assays}

For testing biocompatibility and adhesion of human adipose stem cells (hASC) were isolated from subcutaneous adipose tissue of volunteer female donors undergoing elective liposuction procedures, after obtaining their informed consent according to the procedures approved by the Ethics Committee. ${ }^{38}$ Samples were collected from three different patients aged 25-35 years.

The isolation procedure has been previously established by Zuk et al. ${ }^{39}$ Briefly, the adipose tissue was washed several times with sterile phosphate buffer saline (PBS). Washed aspirates were treated with $0.075 \% \mathrm{w} / \mathrm{v}$ collagenase in PBS (Sigma-Aldrich, Steinheim, Germany) for $30 \mathrm{~min}$ at $37^{\circ} \mathrm{C}$ under gentle agitation. The collagenase was inactivated with an equal volume of control culture media composed of Dulbecco's Modified Eagle Medium (DMEM) supplemented with 10\% fetal bovine serum (FBS) and antibiotics $(100 \mathrm{U} / \mathrm{mL}$ penicillin and $100 \mu \mathrm{g} / \mathrm{mL}$ streptomycin). This suspension was quickly centrifuged $(172 \times g$ for $10 \mathrm{~min})$ and the pellet was resuspended in a control culture medium and filtered through sterile gauze to remove tissue debris. The percentage of living cells was determined by trypan blue staining. Afterwards, cells were seeded in adherent dishes at a density of 12000 cells $/ \mathrm{cm}^{2}$ and incubated in a $5 \% \mathrm{CO}_{2}$ atmosphere at $37^{\circ} \mathrm{C}$. It was important to wash the cells several times with PBS after the 24-h incubation. This manipulation allowed the elimination of non-adherent cells these being mainly dead cells, red blood cells and adipocytes. The medium was replaced every 3 days and split by trypsin treatment when cultures reached $80-90 \%$ of confluence.

In the studies of biocompatibility and adhesion the cells were seeded directly on the materials or were cultured in their presence. The increment in the number of cells on the materials was evaluated through the reduction of tetrazolium salts (MTT) assay. Before the cell culture study, the ceramics were cleaned applying pressured air and rinsed several times with PBS $(\mathrm{pH}$ 7.4). After that, they were dried at $37^{\circ} \mathrm{C}$ and finally the pieces were sterilized by steam autoclave at $125^{\circ} \mathrm{C}$. Then, the discs of ceramic were introduced in the wells of a 24-well culture plate and cells were seeded onto the ceramics at a density of 700 cells $/ \mathrm{mm}^{2}$. hASC were incubated with a final $1 \mathrm{mg} / \mathrm{ml}$ MTT solution with $25 \% \mathrm{FBS}$ and $1 \times \mathrm{PBS}$ for $3 \mathrm{~h}$ at $37^{\circ} \mathrm{C}$ and $5 \% \mathrm{CO}_{2}$ in dark. Cells were washed with $1 \times \mathrm{PBS}$ and incubated with DMSO (Sigma, St. Louis, USA) until the cells were lisated. Absorbance was measured at $570 \mathrm{~nm}$ in a 96-well plate spectrophotometre ( $\mu$ Quant, Biotek instruments INC). Control viability was hASC grew over adherent dishes. Cell adherence and growth were analyzed at $24 \mathrm{~h}$ and 7, 14 and 21 days.

The surface morphology of samples was analyzed by SEMEDS in order to evaluate the cell growth and adhesion to the ceramics surface. After incubation for $24 \mathrm{~h}$ and 7, 14 and 21 days, the samples were removed from the culture well, rinsed with PBS and fixed with $3 \%$ glutaraldehyde in a $0.1 \mathrm{M}$ cacodylate buffer for $1.5 \mathrm{~h}$ at $4{ }^{\circ} \mathrm{C}$. Then they were rinsed and post-fixed in osmium tetroxide for $1 \mathrm{~h}$, before being dehydrated through increasing concentrations of ethanol $(30,50,70$ and 90 vol.\%) with final dehydratation in absolute alcohol. After this, they were dried by the critical-point method and palladium coated and examined by SEM-EDS.

\section{Results}

\subsection{Ceramic characterization}

Stoichiometric quantities of the starting powder, corresponding to the eutectoid composition $69 \mathrm{wt} \%$ dicalcium silicate-31 wt \% tricalcium phosphate (Fig. 1) were mixing miller with PSZzirconia balls, for $1 \mathrm{~h}$, whereby homogeneous powders with an average particle size of $20 \mu \mathrm{m}$ were obtained.

The ceramic cooled inside the furnace to room temperature through the eutectoid point, called 31AC from now on, (label as $A$ in Fig. 2) give a mixture of $\alpha^{\prime}-\mathrm{C}_{2} \mathrm{~S}_{\mathrm{ss}}$ (JCPDS card no.09348) and $\mathrm{A}_{\mathrm{ss}}$ (JCPDS card no.11-0676). On the other hand, the ceramic quenched from $1550{ }^{\circ} \mathrm{C}$ in liquid nitrogen, called $31 \mathrm{R}$ from now on, (label as B in Fig. 2) shows metastable solid solution $\mathrm{R}=\left(\alpha-\mathrm{C}_{2} \mathrm{~S}-\alpha^{\prime}-\mathrm{TCP}\right)$ ss phase. The XRD is characterized by two strong diffraction lines slightly displaced from the strongest lines of $\alpha-\mathrm{C}_{2} \mathrm{~S}$ and $\alpha^{\prime}$-TCP. As all the phases are solid solutions, the diffraction peaks are slightly displaced with respect to the 


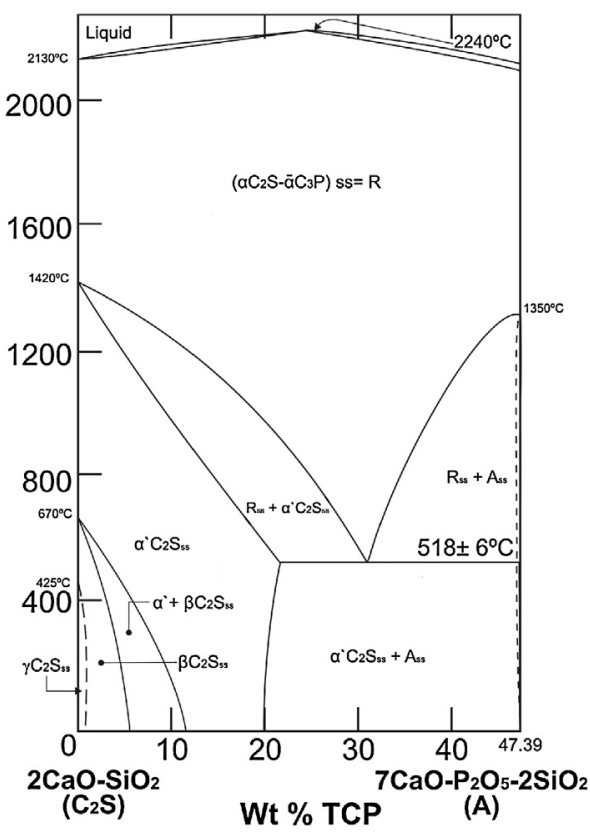

Fig. 1. The sub-system $2 \mathrm{CaOSiO}_{2} \quad\left(\mathrm{C}_{2} \mathrm{~S}\right)-7 \mathrm{CaOP}_{2} \mathrm{O}_{5} 2 \mathrm{SiO}_{2}$ (A) within the system $\mathrm{Ca}_{2} \mathrm{SiO}_{4}-\mathrm{Ca}_{3}\left(\mathrm{PO}_{4}\right)_{2}$. $\left[\mathrm{C}_{2} \mathrm{~S}_{\mathrm{ss}}=\right.$ dicalcium silicate solid solution; $\mathrm{A}_{\mathrm{ss}}=7 \mathrm{CaOP}_{2} \mathrm{O}_{5} 2 \mathrm{SiO}_{2}$ solid solution; $\mathrm{R}=\left(\alpha-\mathrm{C}_{2} \mathrm{~S}-\alpha^{\prime} \mathrm{TCP}\right)$ solid solution. $\mathrm{C}_{3} \mathrm{P}=$ tricalcium phosphate] redraw from phase diagram proposed by Rubio et al. [35].

corresponding JCPDS cards ( $\alpha^{\prime}$-TCP-JCPDS card no. 89-8960 and $\alpha-\mathrm{C}_{2} \mathrm{~S}-\mathrm{JCPDS}$ card no. 87-1260).

The $31 \mathrm{AC}$ ceramic specimens after chemical etching $(0.5 \%$ acetic acid for $2 \mathrm{~s}$ ) present an irregular eutectoid structure of lamellae morphology as expected (Fig. 3A). The sample was made up of very thin eutectoid platelets that constituted of $\alpha^{\prime}$ $\mathrm{C}_{2} \mathrm{~S}_{\mathrm{ss}}$ and $\mathrm{A}_{\mathrm{ss}}$ phases. EDS microanalysis showed that the lightcontrast phase corresponded to $\alpha^{\prime}-\mathrm{C}_{2} \mathrm{~S}_{\mathrm{ss}}$, while the darker phase was $A_{\text {ss. }}$. Fig. 3B shows the microstructure of the sample 31R. The material presents homogenous microstructure of only one phase with irregular grains and closed pores. EDS confirmed the presence of phosphorous, calcium and silicon.

For a comprehensive microstructural characterization of the materials, microstructural parameters, such a crystalline size, porosity, density and shrinkage of the samples, have been established (Table 1).

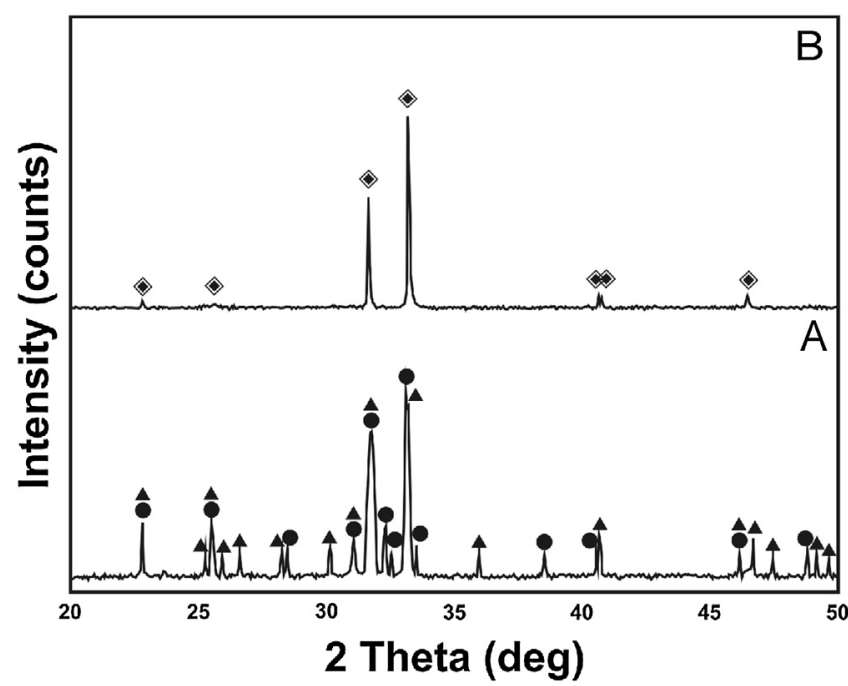

Fig. 2. X-ray diffraction patterns of the eutectoid ceramics $31 \mathrm{AC}$ (A) and $31 \mathrm{R}$ (B) materials studied [ $\boldsymbol{\Lambda}=$ Ass; $\left.\bullet=\alpha^{\prime} \mathrm{C}_{2} \mathrm{Sss} ; \diamond=\mathrm{Rss}\right]$.

\subsection{In vitro test in $S B F$}

The surface morphologies of the ceramics after different soaking times in SBF are shown in Fig. 4. The surface after 3 days of soaking of the $31 \mathrm{AC}$ ceramic (Fig. $4 \mathrm{~A}$ ) presents a porous lamellae morphology, formed by reaction of the eutectoid material with the SBF causing selective dissolution of one of the phases which forms the lamellae of the eutectoid material and the subsequent formation of apatite-like lamellae by a pseudomorphic transformation of one of the phases $\left(\alpha^{\prime}-\mathrm{C}_{2} \mathrm{~S}_{\mathrm{ss}}\right.$ or the $\mathrm{A}_{\mathrm{ss}}$ ) which form the ceramic material. This is confirmed by EDX microanalyses that show that the porous lamellae morphology is formed by calcium and phosphorus and traces of silica (data not shown). The morphology of the single phase eutectoid material, 31R, is completely different (Fig. 4D). The surface is partially covered by spherical particles smaller than $1.0 \mu \mathrm{m}$. In some areas the particles are forming small agglomerates. Fig. 4B and E shows the SEM images of the surface of both eutectoid materials after soaking for 7 days. After immersion, the ceramic surfaces were covered by a layer of agglomerates of globular particles. The morphology of precipitation was quite similar among the ceramic surfaces during the in vitro assay; a

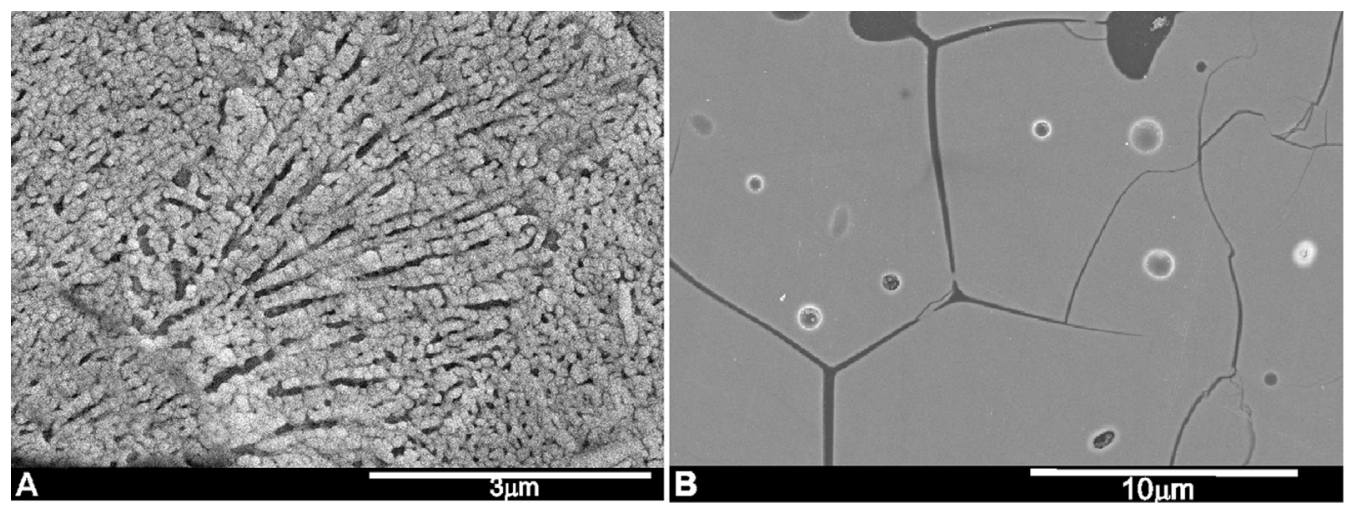

Fig. 3. SEM micrographs of chemical etched surface of the $31 \mathrm{AC}(\mathrm{A})$ and $31 \mathrm{R}(\mathrm{B})$ ceramics.

Please cite this article in press as: Rubio V, et al. Preparation, characterization and in vitro behavior of a new eutectoid bioceramic. $J$ Eur Ceram Soc (2014), http://dx.doi.org/10.1016/j.jeurceramsoc.2014.08.039 
Table 1

Physical characteristic of the eutectoid ceramics.

\begin{tabular}{|c|c|c|c|c|c|}
\hline & Crystalline phases & Crystallite size (Scherrer) (§) & Porosity $(\%)$ & Density $\left(\mathrm{g} / \mathrm{cm}^{3}\right)$ & Shrinkage $(\%)$ \\
\hline $31 \mathrm{AC}$ & $\alpha^{\prime} \mathrm{C}_{2} \mathrm{~S}_{\mathrm{ss}}+\mathrm{A}_{\mathrm{ss}}$ & 339.44 & 9.10 & 2.53 & $7.23 \pm 0.5$ \\
\hline $31 \mathrm{R}$ & $\mathrm{R}_{\mathrm{ss}}$ & 578.95 & 13.85 & 2.22 & $5.63 \pm 0.5$ \\
\hline
\end{tabular}
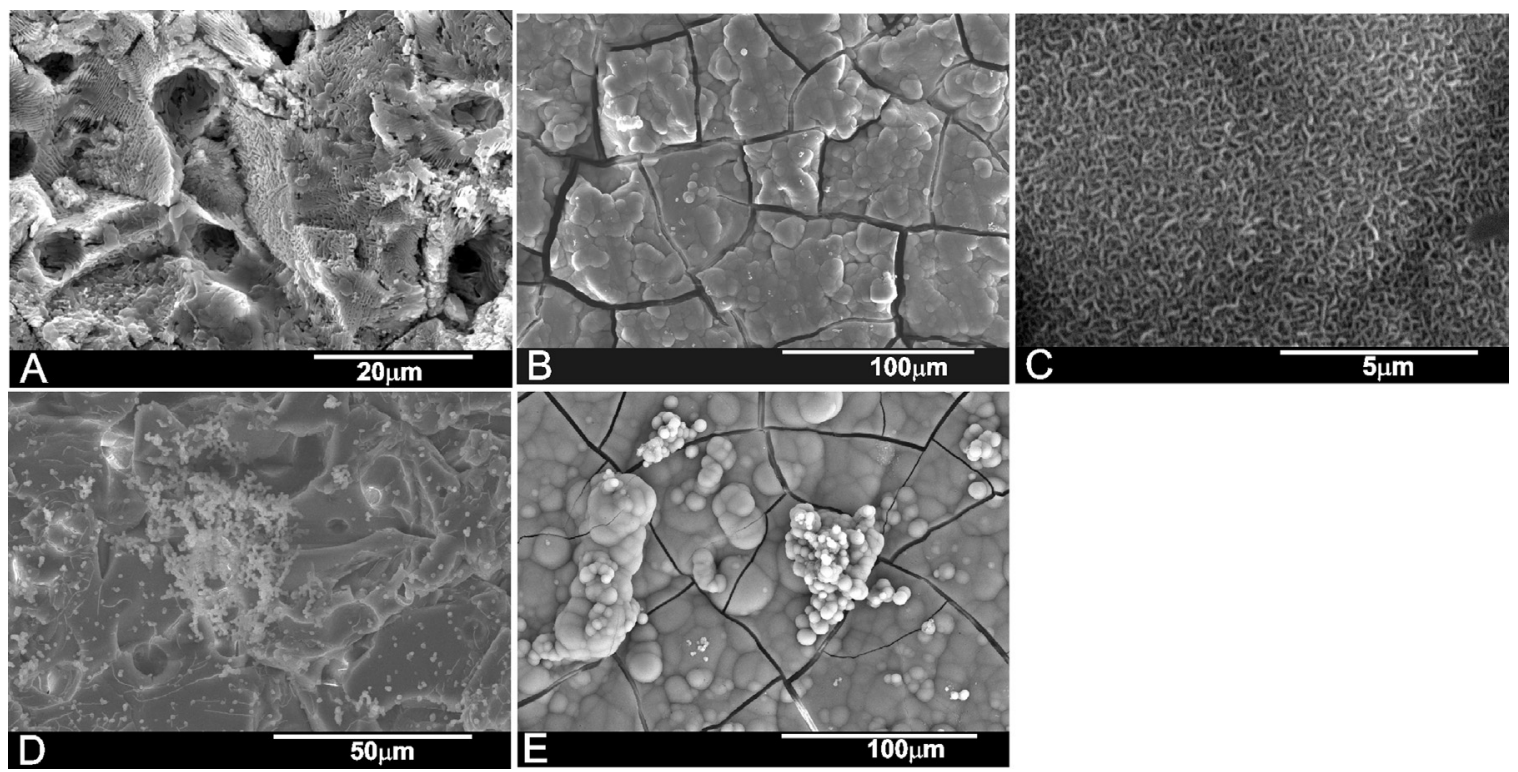

Fig. 4. SEM images of the $31 \mathrm{AC}(\mathrm{A}-\mathrm{C})$ and $31 \mathrm{R}$ (D,E) ceramic surfaces morphologies after soaking times in SBF (A,D) 3 days, (B,E) 7 days and (C) 14 days.

globular phase grew gradually forming a compact and continuous layer on the surface, as a result, the original morphology of the ceramic surfaces were completely changed (Fig. 3). This morphology does not further change with soaking time although with longer immersion periods, the $\mathrm{Ca}-\mathrm{P}$ spheres became bigger, with a final average diameter of $\sim 20 \mu \mathrm{m}$ after 14 days of immersion and joined as a larger dense layer. Some microcracks could also be observed on the ceramic surfaces caused by the shrinkage of the soaked samples in air, suggesting the formation of a thick deposition layer. After soaking for 14 days, more $\mathrm{Ca}-\mathrm{P}$ agglomerates grew on both ceramic surfaces and the $\mathrm{Ca}-\mathrm{P}$ layer became more compact (data not shown). The higher magnification SEM image as a representative of both ceramic surface precipitated revealed that the agglomerated were composed of a large number of tiny worm-like crystals with a size of crystallites about $300-400 \mathrm{~nm}$ in length and $100 \mathrm{~nm}$ in diameter (Fig. 4C). These small agglomerate particles were determined to be apatite-like although from SEM-EDS microanalysis. The $\mathrm{Ca} / \mathrm{P}$ ratio of the apatite-like layer was in average $\sim 2.4$, higher than that in HA stoichiometric. This fact suggests that a Ca deficient hydroxyapatite (CHA) is forming on the surface of both eutectoid ceramics.

The microstructure of polished cross-sections of the 31AC material after soaking in SBF for 3 and 7 days are shown in Fig. 5. The label ${ }^{*}$ in Fig. 5A and $\mathrm{C}$ shows a porous layer of reaction products developed on the surface of the eutectoid ceramic, and Fig. 5B a close-up image of this reaction zone. The layer, about $12( \pm 0.05) \mu \mathrm{m}$ thick, was composed on average of $58.45 \mathrm{~atm} \%$ $\mathrm{Ca}, 32.75 \mathrm{~atm} \% \mathrm{P}$ and $1.83 \mathrm{~atm} \% \mathrm{Si}$, and had $\mathrm{Ca}$ and $\mathrm{Si}$ lower than the original specimen (label as $\mathbf{\square}$ ). For the specimen soaked in SBF for 7 days (Fig. 5C) the microstructural study revealed the formation of two well-defined successive layers at the interface. A massive formation of a new dense CHA layer was observed at the SBF-sample interface $(2.08 \leq \mathrm{Ca} / \mathrm{P} \leq 2.14)$. Adjacent to the dense CHA layer a porous structure has been developed parallel to the interface (label as * in Fig. 5C) which is formed by the dissolution of one of the phases which forms the material $(1.66 \leq \mathrm{Ca} / \mathrm{P} \leq 2.06)$. On the other hand, the $31 \mathrm{R}$ ceramic (Fig. 6 ) shows at 7 days of soaking a dense precipitated of HCA growing in direct contact with the ceramic substrate $(1.68 \leq \mathrm{Ca} / \mathrm{P} \leq 2.03)$.

Table 2 shows the change of thickness of the CHA layer as a function of the soaking time. It was found that the porous reaction zone in $31 \mathrm{AC}$ material increased up to about 16.10

Table 2

Thickness of the layer formed in the ceramic-SBF interfaces as a function of soaking time (error \pm 0.05 ).

\begin{tabular}{llll}
\hline $\begin{array}{l}\text { Days } / \mu \mathrm{m} \\
( \pm 0.05)\end{array}$ & $31 \mathrm{AC}$ & & $31 \mathrm{R}$ \\
\cline { 2 - 3 } & Porous layer & Dense layer & \\
\hline 1 & 0 & 0 & Dense layer \\
3 & 12.00 & 0 & 8.38 \\
5 & 13.86 & 25.86 & 20.02 \\
7 & 15.00 & 31.34 & 27.78 \\
9 & 15.62 & 32.35 & 30.67 \\
11 & 15.94 & 36.13 & 33.35 \\
13 & 16.04 & 36.06 & 34.25 \\
14 & 16.10 & 35.10 & 34.86 \\
\hline
\end{tabular}




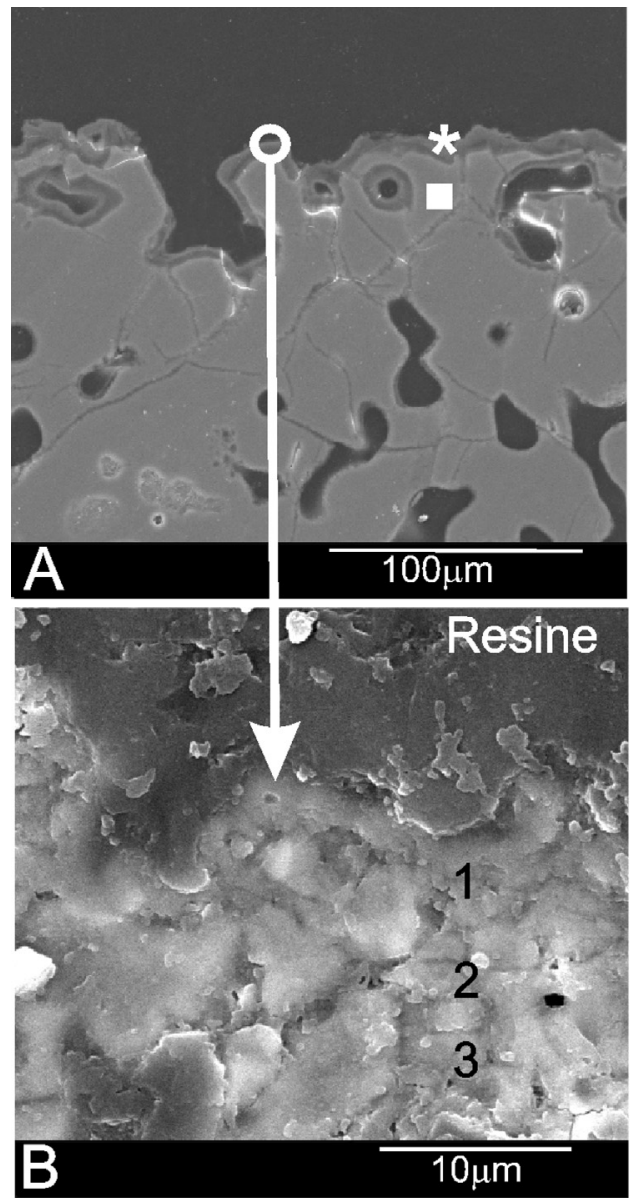

\begin{tabular}{|c|c|c|c|}
\hline \multicolumn{4}{|c|}{ EDS microanalysis of Figure $5 \mathrm{~A}$} \\
\hline \multirow{2}{*}{ Zone } & \multicolumn{3}{|c|}{ Atomic \% } \\
\cline { 2 - 4 } & $\mathrm{Ca}$ & $\mathrm{P}$ & $\mathrm{Si}$ \\
\hline$*$ & 58.05 & 31.96 & 1.29 \\
\hline $\mathbf{n}$ & 66.66 & 12.05 & 21.29 \\
\hline
\end{tabular}

\section{EDS microanalysis of Figure 5B}

\begin{tabular}{|c|c|c|c|}
\hline \multirow{2}{*}{ Zone } & \multicolumn{3}{|c|}{ Atomic \% } \\
\cline { 2 - 4 } & $\mathrm{Ca}$ & $\mathrm{P}$ & $\mathrm{Si}$ \\
\hline 1 & 60.13 & 36.31 & 1.93 \\
\hline 2 & 61.57 & 36.55 & 2.01 \\
\hline 3 & 54.09 & 26.18 & 2.13 \\
\hline
\end{tabular}

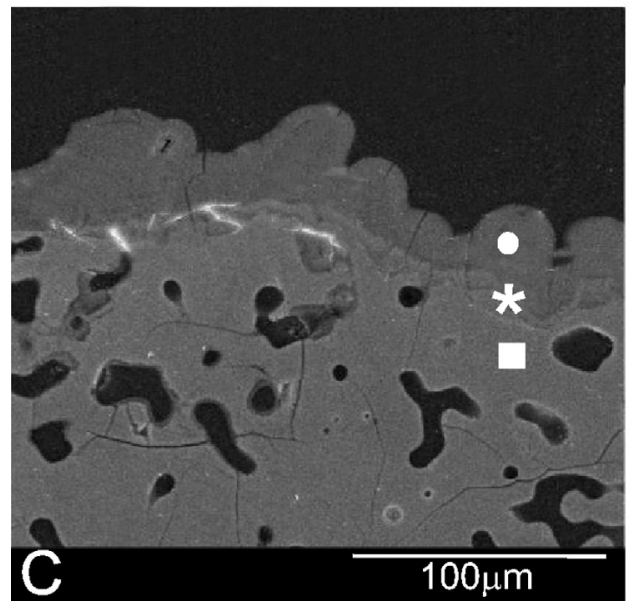

\begin{tabular}{|c|r|c|c|}
\hline \multicolumn{4}{|c|}{ EDS microanalysis of Figure $5 \mathrm{C}$} \\
\hline \multirow{2}{*}{ Zone } & \multicolumn{3}{|c|}{ Atomic $\%$} \\
\cline { 2 - 4 } & $\mathrm{Ca}$ & $\mathrm{P}$ & $\mathrm{Si}$ \\
\hline $\mathbf{D}$ & 61.96 & 28.88 & 1.07 \\
\hline $\boldsymbol{*}$ & 59.36 & 35.54 & 2.14 \\
\hline$\square$ & 67.51 & 12.41 & 22.94 \\
\hline
\end{tabular}

Fig. 5. SEM cross-section view to the $31 \mathrm{AC}$ bioceramic immersed in SBF for (A, B) 3 days and (C) 7 days and EDS microanalysis.

$( \pm 0.05) \mu \mathrm{m}$ thickness after 14 days soaking, while the dense CHA layer reach about $35.10( \pm 0.05) \mu \mathrm{m}$ for the same period of soaking. On the other hand the $31 \mathrm{R}$ ceramic does not presents an intermediate porous layer. After 1 and 3 days of soaking the surface of $31 \mathrm{R}$ sample was partially dissolved in the SBF, forming a dense layer parallel to the SBF-ceramic, and in the areas where the layer is present, this is about $8.38( \pm 0.05) \mu \mathrm{m}$ thickness, reaching a final thickness of $35.04( \pm 0.05) \mu \mathrm{m}$ after 14 days of soaking.

Changes in calcium, phosphorous and silicon ions concentrations of SBF measured at different days of soaking are shown in Fig. 7. Both eutectoid ceramic materials released Si ions and removed $\mathrm{P}$ ions from the SBF in a similar way, but in different amounts. The main difference is in relation to $\mathrm{Ca}$ ion profile, indicating a different in vitro behavior. The continuous Si ion dissolution from the material contributed to generate an increase on the Si ion concentration in the SBF. The specific concentration of $\mathrm{Si}$ in SBF increased from 0 to 0.92 and $0.52 \mathrm{mMol}$ for $31 \mathrm{AC}$ and $31 \mathrm{R}$, respectively, when soaked for 14 days. In addition, phosphorous ions were removed from SBF by both sintered ceramics, because the formation of $\mathrm{CHA}$ phase on the surface of the material and its concentration decreased from 1.0 to 0.2 


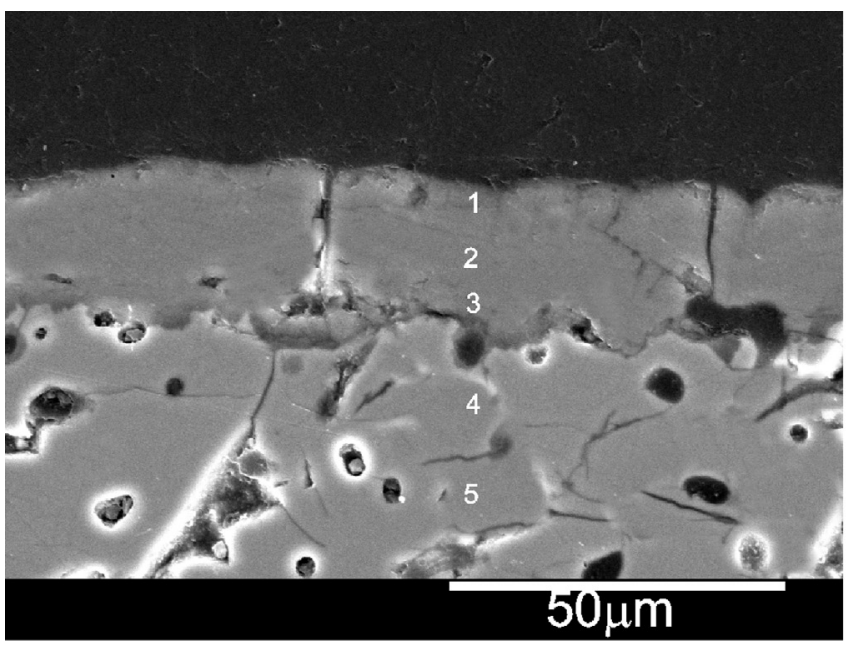

\begin{tabular}{|c|c|c|c|}
\hline \multirow{2}{*}{ EDS microanalysis of Figure 6 } \\
\hline \multirow{2}{*}{ Zone } & \multicolumn{3}{|c|}{ Atomic \% } \\
\cline { 2 - 4 } & $\mathrm{Ca}$ & $\mathrm{P}$ & $\mathrm{Si}$ \\
\hline 1 & 56.42 & 33.45 & 1.03 \\
\hline 2 & 53.42 & 30.56 & 1.94 \\
\hline 3 & 55.39 & 27.26 & 2.29 \\
\hline 4 & 64.24 & 12.31 & 23.45 \\
\hline 5 & 64.50 & 12.15 & 23.35 \\
\hline
\end{tabular}

Fig. 6. SEM cross-section view to the 31R bioceramic immersed in SBF for 7days and EDS microanalysis.

and $0.19 \mathrm{mMol}$ for $31 \mathrm{AC}$ and $31 \mathrm{R}$, respectively. After 14 days of soaking, the formation rate gradually showed down due the depletion of Pion concentration from the SBF solution and diffusion processes of ions across the new $\mathrm{CHA}$ layer, which becomes very difficult. In contrast, the $\mathrm{Ca}$ ion concentration decrease from 2.5 to $1.86 \mathrm{mMol}$ for $31 \mathrm{AC}$ and increased from 2.5 to 3.90 for $31 \mathrm{R}$ ceramic.

TEM and SAD were used to examine the ultrastructure of the surface product formed after the exposure of the 31AC (Fig. 8A-F) and 31R (Fig. 8G and H) samples to SBF for different soaking times. The results showed the presence of nanocrystals with a plate-like morphology, mainly composed of $\mathrm{Ca}$ and $\mathrm{P}$.

\subsection{Cell adhesion and proliferation assays.}

Fig. 9 shows the morphology of hASC adhering and spreading on 31R (A-D) and 31 AC (E-H) ceramic samples after culturing for $24 \mathrm{~h}, 7,14$ and 21 days. When compared with the orifinal surface, before exposure to cell culture medium (Fig. 3), it became evident that the surface morphology was altered.

On $24 \mathrm{~h}$ incubation (Fig. 9A and E) the adhesion was enhanced by means of multiple cytoplasmic digitations that spread across the granular surface of the material, increasing the contact area with the surface of the material. At this period the cells in all the ceramics studied presents a similar morphology showing some cells adhering either individually or in small groups dispersed across the surface of the material. After 7 days exposure, there was a significant increase in the cell growth rate on the ceramic surfaces. The cells formed a monolayer partially covering the $31 \mathrm{R}$ surface (Fig. 9B) and produced an extracellular matrix of a fibber network occupying the intercellular gaps. On the 31AC surface (Fig. 8F) cell-to-cell contact was frequent, with numerous intercellular gaps present.

After a period of 14 days, the cells began to form a monolayer on all tested materials. The cell monolayer appeared almost continuous with the cells exhibiting flattened and spread morphology. Although in the 31AC ceramic (Fig. 9G) it was not possible to see the material surface underneath. At the end of the experiment (21 days) the monolayer fully covers the surface of both materials. In the case of 31R ceramic (Fig. 9D) some ruptured cells were visible, while in the case of the $31 \mathrm{AC}$ materials cells showed a tendency to orientate in the same directions (Fig. 9H).

Fig. 10 shows a detail of the morphology of the hASC adhering and spreading on $31 \mathrm{R}$ ceramics after incubation for 21 days. Abundant extra-cellular matrix was observed at this time. The intercellular gaps were occupied by abundant fibrillar material, with deposits of mineral forming and extra-cellular matrix. Furthermore, the cell surface showed a granular appearance due to the presence of numerous nodules with a whitish appearance emerging from the surface. To determine the nature of the
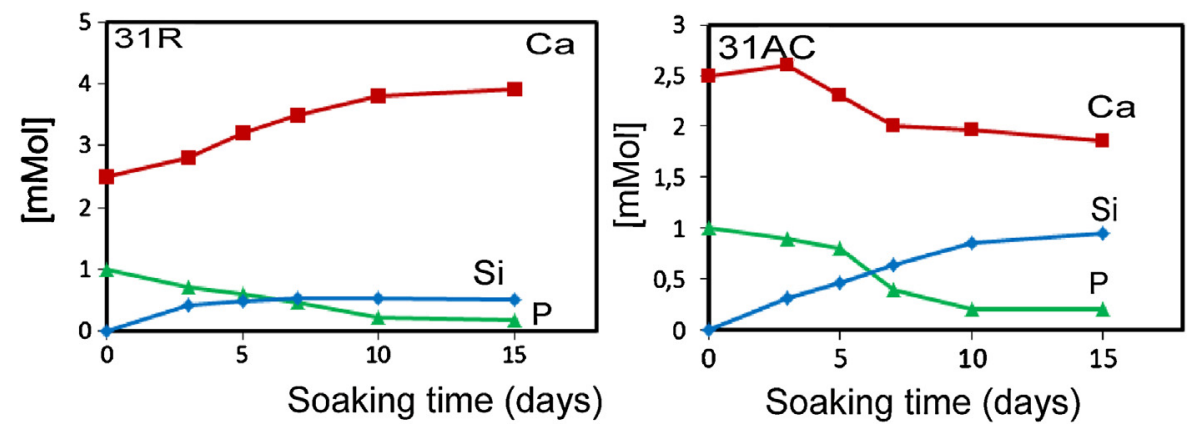

Fig. 7. Change in calcium $(\mathrm{Ca})$, phosphorus $(\mathrm{P})$ and silicon $(\mathrm{Si})$ ion concentration with soaking in SBF solution. 

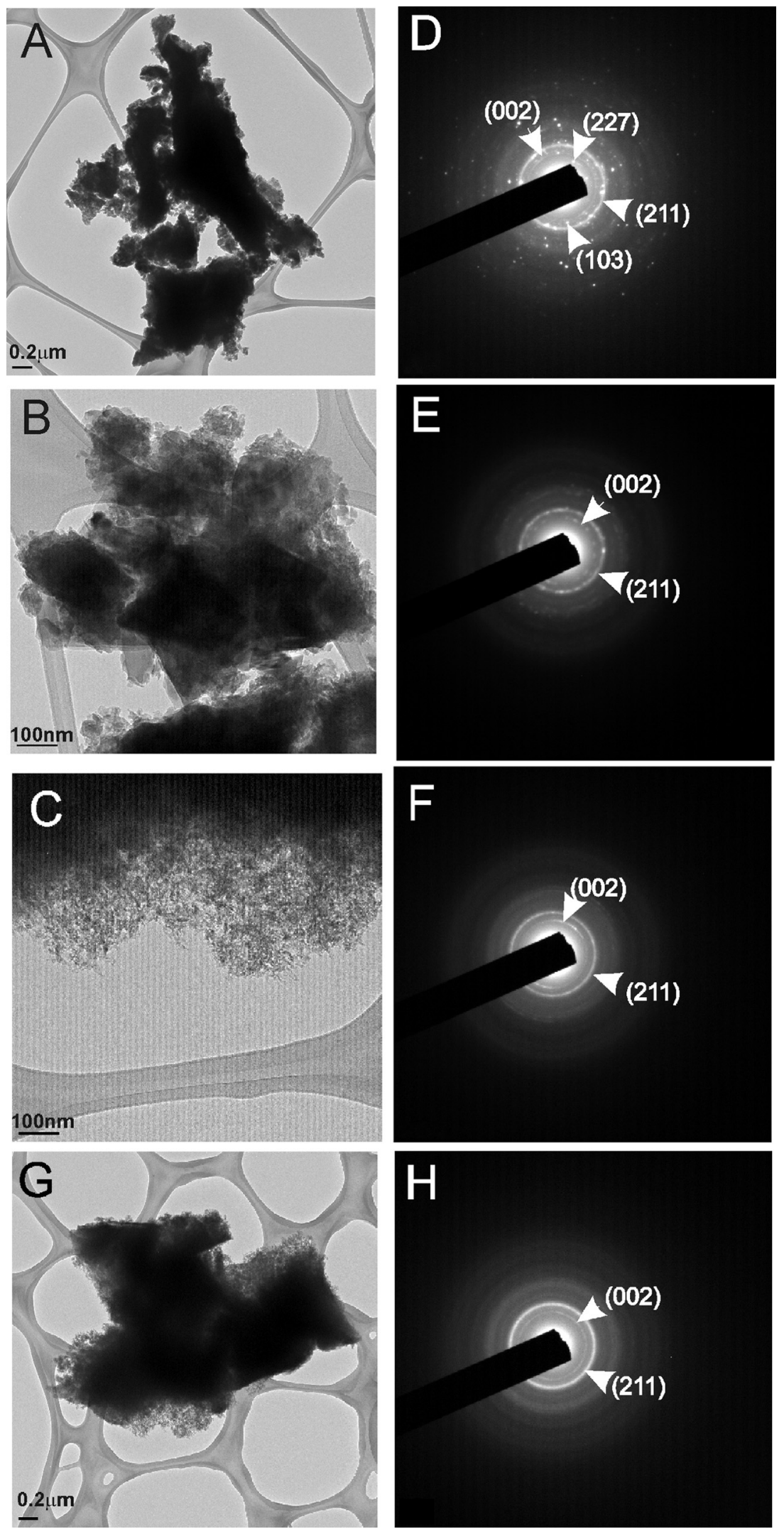

Fig. 8. TEM micrographs and SAD of the surface product from the $31 \mathrm{AC}(\mathrm{A}-\mathrm{F})$ and $31 \mathrm{R}(\mathrm{G}, \mathrm{H})$ ceramics exposure to SBF for different times. (A,D) 3 days, (B,E) 7 days and $(\mathrm{C}, \mathrm{F}-\mathrm{H}) 14$ days. 

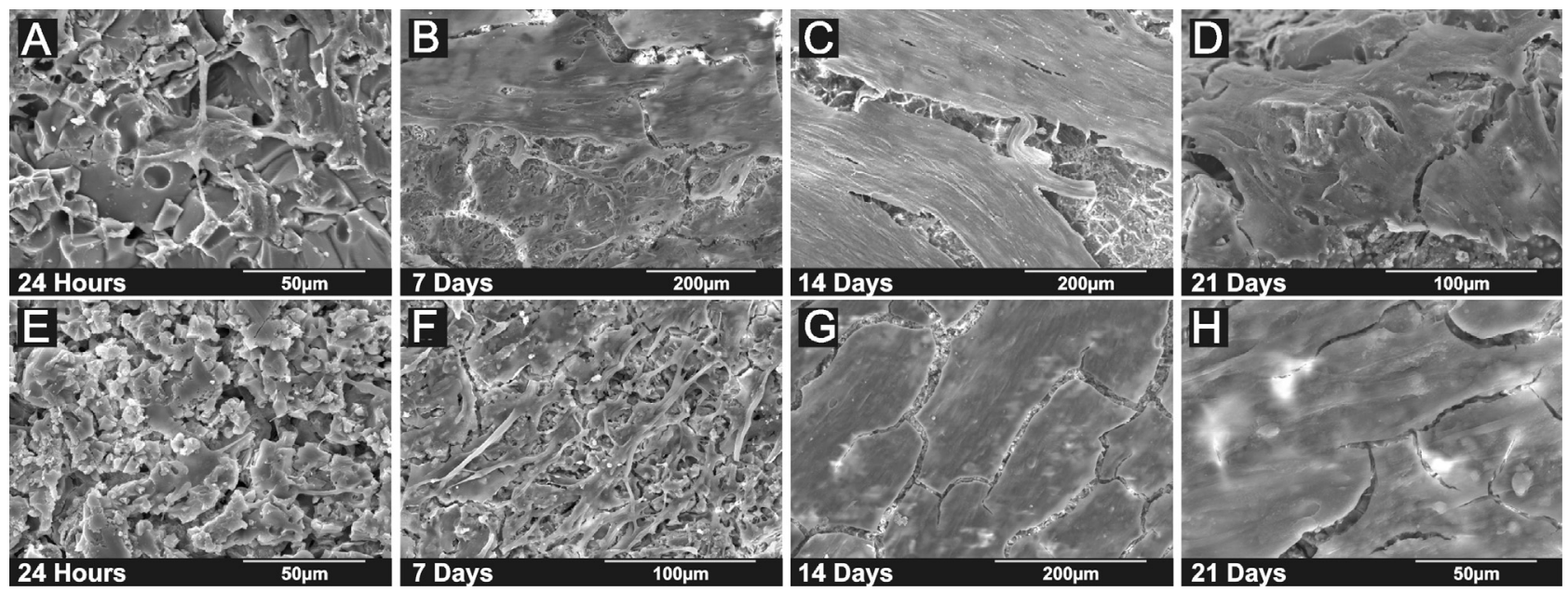

Fig. 9. SEM images of the morphology of hASC growing on the $31 \mathrm{AC}(\mathrm{A}-\mathrm{D})$ and $31 \mathrm{R}(\mathrm{E}-\mathrm{H})$ ceramic surfaces after different seeded time.

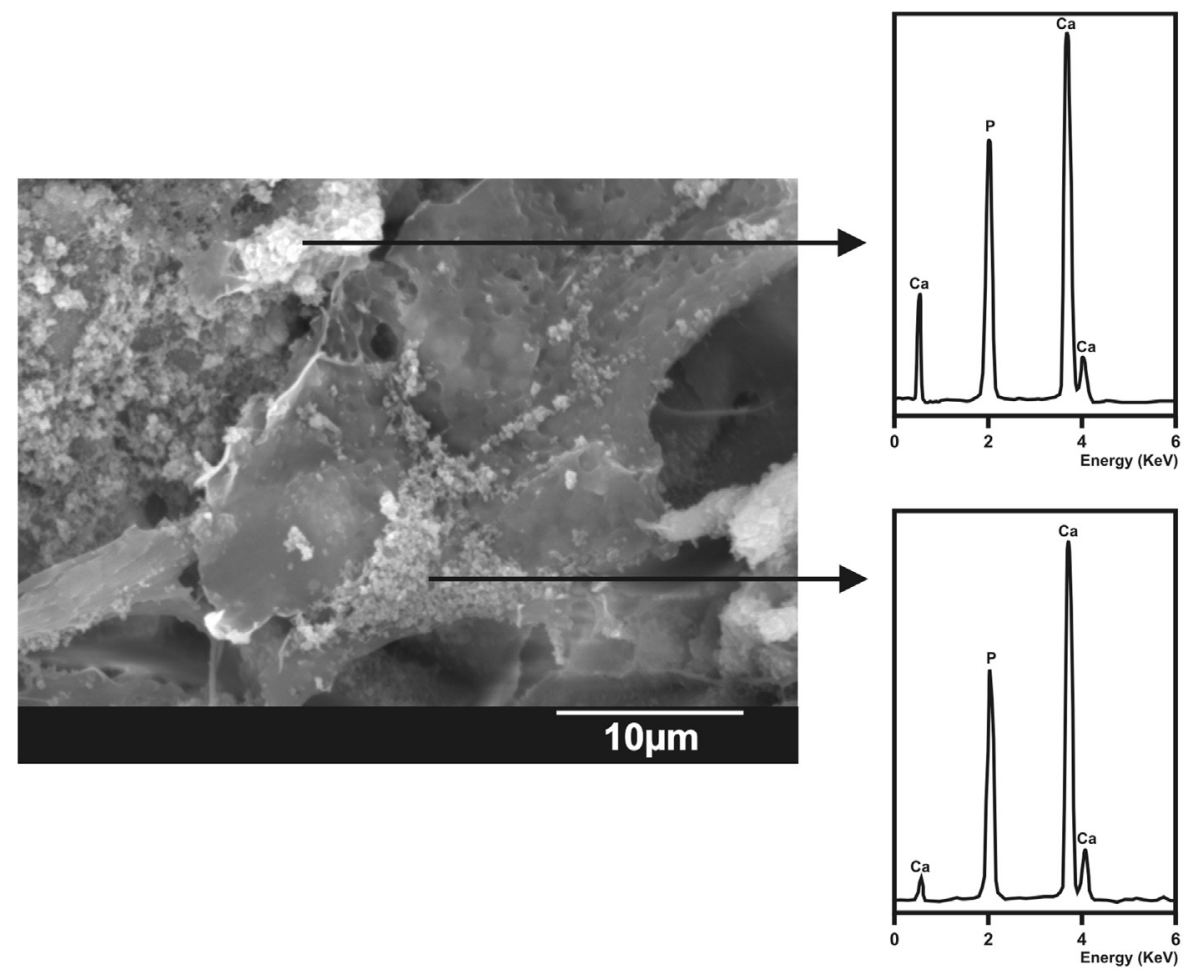

Fig. 10. SEM-EDS microanalysis of the cytoplasmatic glanules of the hASC growing on the 31R surface after 21 days.

nodules, microanalysis by EDS was carried out. This analysis proved that it was a calcium phosphate-based material. It is worth noting that this EDS spectrum is different to that of the material surface, which showed peaks corresponding to $\mathrm{Si}, \mathrm{Ca}$ and $\mathrm{P}$.

Measures of MTT cell proliferation assay confirmed the SEM observations. Fig. 11 shows the proliferation of hASC on the $31 \mathrm{R}$ and $31 \mathrm{AC}$ ceramics throughout the time of the study. The viability values detected at $24 \mathrm{~h}$ were very low, indicating that the number of cells initially adhered to both the ceramics were small. However, the growth of those cells able to attach to the biomaterials progressed linearly with time. The number of cells growing on $31 \mathrm{R}$ ceramic was always slightly lower than those obtained on 31 AC, although there were no significant differences between them.

\section{Discussion}

By controlling the heat treatment we were able to design two materials with the same chemical composition but different microstructure: Slow cooling treatment produces a eutectoid ceramic with lamellae morphology of $\alpha^{\prime}-\mathrm{C}_{2} \mathrm{~S}_{\mathrm{ss}}$ and $\mathrm{A}_{\mathrm{ss}}$ phases (Fig. 3A). Quenching method at high temperature produce a single polycrystalline solid solution $\mathrm{R}=\left(\alpha-\mathrm{C}_{2} \mathrm{~S}-\alpha^{\prime}-\mathrm{TCP}\right)$ ss phase (Fig. 3B) in agreement with the temperature of the eutectoid 


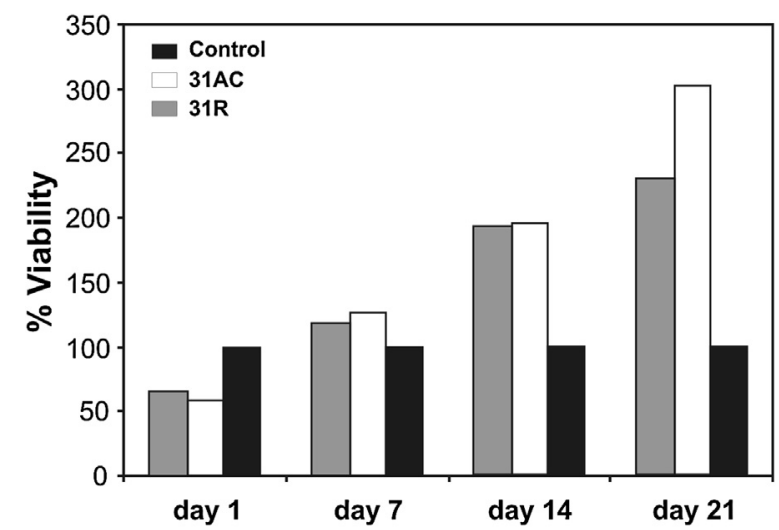

Fig. 11. Growth of hASC on the $31 \mathrm{R}$ and $31 \mathrm{AC}$ ceramics at different times of studied.

point (Fig. 1) established by Rubio et al. ${ }^{35}$ The thermal treatments generated shrinkage in both the materials, as shown in Table 1 . The tendency for the density was to increase with the increasing amounts of shrinkage, in this way it was possible to observe that the sample that shows highest shrinkage, corresponding to $31 \mathrm{AC}$, showed also the highest density, although there is no great differences between them.

It is obvious from the results described above that both the ceramics shows strong in vitro bioactive behavior when soaking in SBF. The property of having a bioactive surface is related to the formation of a CHA layer when the material comes into contact with SBF. It is considered that bonelike CHA plays an essential role in the formation, growth and maintenance of the chemical bond of the bioactive material to the living bone. In the present work, the combined SEM-EDS, TEM-SAD and ICP-OES analyses showed that all the studied ceramics presented in vitro bioactivity. Both materials are bioactive but with different behavior.

In relation to $31 \mathrm{AC}$ material, the recorded changes in the concentration of the different ions (Fig. 7) showed that during the first stage of soaking the material released $\mathrm{Ca}$ and $\mathrm{Si}$ ions. On the other hand, the concentration of silicon was increasing continuously during all the experiment reaching $0.92 \pm 0.04 \mathrm{mMol}$ after 14 days. It means that the phase or phases that were dissolving contained high content of silicon. Therefore these will be the $\alpha^{\prime}-\mathrm{C}_{2} \mathrm{~S}_{\mathrm{ss}}$ and/or the $\mathrm{A}_{\text {ss. }}$. The degradation of the both phases led to the formation of a porous reaction layer of $16.10( \pm 0.05) \mu \mathrm{m}$ of thickness after 14 days of soaking (Fig. 5 and Table 2). During the second stage of soaking about 7 days, the concentration of $\mathrm{Ca}$ ions in the SBF decreased up to $2.0 \pm 0.03 \mathrm{mMol}$ due to the precipitation of a CHA layer on the ceramic surface (Figs. 4A-C and 5). The $\mathrm{P}$ concentration also decreased up to $0.4 \pm 0.06 \mathrm{mMol}$ in the course of 7 days. This decrease observed up to 7 days of soaking to SBF was more prominent due to the formation of the HCA layer of about $31.34( \pm 0.05) \mu \mathrm{m}$ thickness. During the first stages of the reaction, the high calcium concentration in the SBF solution (Fig. 7) enhanced the later nucleation of CHA layer on the surface of the specimen, with high $\mathrm{Ca} / \mathrm{P}(2.08 \leq \mathrm{Ca} / \mathrm{P} \leq 2.14)$. The EDS microanalyses presented in Fig. 5 provided data for $\mathrm{Ca} / \mathrm{P}$ ratio calculations for HCA as a function of soaking time. The subsequent changes in the ion concentration in the SBF solution suggest that the diffusion process of the ions took place through the pores of the porous reaction layer generated by degradation of the $\alpha^{\prime}-\mathrm{C}_{2} \mathrm{~S}_{\mathrm{ss}}$ and/or $\mathrm{A}_{\mathrm{ss}}$ at the $31 \mathrm{AC}$ ceramic-SBF interface (Fig. 5). This explains why after 14 days period, the $\mathrm{Si}$ content within the SBF was still increasing (Fig. 7).

The TEM/SAD results were essential in understanding these processes. Fig. 8A shows a TEM image of the removed reaction product from the $31 \mathrm{AC}$ ceramic soaked in SBF for 3 days. SAD in Fig. 8D clearly indicates the preferential orientation of the CHA crystals in [0 02] direction, in addition to some particles from the starting material since some diffraction spots correspond to the $\mathrm{C}_{2} \mathrm{~S}$ and $\mathrm{A}$ phases. A comparison with the $\mathrm{SAD}$ of the removed surface product from the ceramic soaked in SBF for 7 days in Fig. 8E indicated that the amount of CHA crystals was significantly smaller than in 14 days sample (Fig. 8F), because the $\left(\begin{array}{ll}0 & 02\end{array}\right)$ arc was less prominent. Overall, these complementary TEM/SAD data confirmed that a quantity of a new CHA phase precipitated on the surfaces of the $31 \mathrm{AC}$ ceramics was a function of soaking time in the SBF solution.

The mechanism of the formation of the CHA layer on $31 \mathrm{AC}$ ceramics can be as follows:

Dissolution of $\alpha^{\prime}-\mathrm{C} 2 \mathrm{Sss}$ in SBF with release of $\mathrm{Ca}^{2+}$ and $\mathrm{HSiO}_{4}{ }^{-}$, as majority ions, and increase in $\mathrm{Ca}^{2+}, \mathrm{HSiO}_{4}{ }^{-}$and $\mathrm{OH}^{-}$ionic activities at the neighborhood of the reacting surface until they exceed the solubility product of the HA:

$\mathrm{Ca}_{2} \mathrm{SiO}_{4}+\mathrm{H}_{2} \mathrm{O} \rightarrow 2 \mathrm{Ca}^{2+}+\mathrm{HSiO}_{4}{ }^{-}+\mathrm{OH}^{-}$

With the release of the calcium ions from the dicalcium silicate solid solution, many $\mathrm{Si}-\mathrm{OH}$ groups are formed on the surfaces of $31 \mathrm{AC}$. These silanol groups induce heterogeneous nucleation of apatite, and the released calcium ions increase the ionic activity product of apatite, enhancing apatite nucleation.

Partial dissolution of A-phase in $\mathrm{SBF}$ with release of $\mathrm{SiO}_{4}{ }^{4-}$, $\mathrm{HPO}_{4}{ }^{2-}$ and $\mathrm{Ca}^{2+}$

$$
\begin{gathered}
\mathrm{Ca} 7\left(\mathrm{PO}_{4}\right)_{2}\left(\mathrm{SiO}_{4}\right)_{2}+2 \mathrm{H}_{2} \mathrm{O} \rightarrow 2 \mathrm{SiO}_{4}{ }^{4-}+2 \mathrm{HPO}_{4}{ }^{2-} \\
+7 \mathrm{Ca}^{2+}+2 \mathrm{OH}^{-}
\end{gathered}
$$

Next the nucleation of a CHA layer takes place on the surface of the material, by reaction of the SBF phosphate ions with the excess of calcium ions liberated to SBF by the ceramic. The silicate ions liberated by the ceramic can produce silicon-HA. Data from SEM-EDS suggest a very small quantity of silicon substitution on the apatite phase according to 61.96/28.88/1.07 $(\mathrm{Ca} / \mathrm{P} / \mathrm{Si} \mathrm{atm} \%)$ :

$$
\begin{aligned}
& (6-x) \mathrm{HPO}_{4}{ }^{2-}+y \mathrm{SiO}_{4}{ }^{4-}+10 \mathrm{Ca}^{2+}+8 \mathrm{OH}^{-} \\
& \quad \rightarrow \mathrm{Ca}_{10-x}\left(\mathrm{HPO}_{4}\right)_{x}(\mathrm{PO} 4)_{6-y}\left(\mathrm{SiO}_{4}\right)_{y}(\mathrm{OH})_{2-x}+6 \mathrm{H}_{2} \mathrm{O}
\end{aligned}
$$

Once apatite nuclei are formed on the surface of the porous layer, they can grow spontaneously by consuming calcium and phosphate ions from the surrounding SBF solution.

The results showed that the morphology generated in the SBF was controlled by different phases' solubility which generated 
changes of the surface chemistry and the surface topography. This mechanism leads to the "in situ" formation of a porous interconnected structure of silicon-HA, which could be expected to promote the bone growth when the eutectoid ceramic is implanted into bone defects.

In relation to $31 \mathrm{R}$ material, the recorded changes in the concentration of the different ions (Fig. 7) showed that $\mathrm{Ca}$ and $\mathrm{Si}$ ions' concentration increased with the increase in the soaking time. In contrast, the $\mathrm{P}$ ion concentration in SBF decreased steeply to level that was only $23 \%$ of the starting concentration after soaking for 10 days, and then remained at this level afterwards. The increase in $\mathrm{Ca}$ and $\mathrm{Si}$ concentrations was attributed to the dissolution of calcium and silicate ions from $\mathrm{R}=\left(\alpha-\mathrm{C}_{2} \mathrm{~S}-\alpha^{\prime}-\right.$ TCP)ss ceramics, and phosphate ions in the immersion solution were consumed with the formation of $\mathrm{CHA}$, which resulted in the decrease of $\mathrm{P}$ concentration. Although some calcium ions were consumed to form CHA, more calcium ions were dissolved from the ceramic matrix than those were consumed. It is expected that the process of the new CHA layer formation at the surface of the $31 \mathrm{R}$ ceramic would continue for as long as the ion exchange mechanism between the material and the SBF takes place. It is expected that the process will come to the end when the supply of the $\mathrm{P}$ ions from the SBF terminates, or if the diffusion of the ions across the interface is stopped due to the thickness of the new CHA layer reaching a critical value. SAD study performed in TEM (Fig. 8G and $\mathrm{H}$ ) showed that the CHA phase is composed of nanocrystals with a plate-like morphology. When the specimen was appropriately oriented, the SAD often displayed $\left(\begin{array}{ll}0 & 0\end{array}\right)$ and $(210)$ arcs indicating the preferential orientation of the CHA crystals in the layer.

The differences in microstructure between the $31 \mathrm{AC}$ and $31 \mathrm{R}$ eutectoid ceramics are considered to influence the formation of CHA layer on their surfaces. The differences observed between the samples studied can be explained in terms of the differences in phase solubility. The formation of a CHA-layer in the surface is attributed to a higher rate of dissolution of $\alpha^{\prime}-\mathrm{C} 2 \mathrm{Sss}$ and Ass vs $\mathrm{R}=\left(\alpha-\mathrm{C} 2 \mathrm{~S}-\alpha^{\prime}-\mathrm{TCP}\right)_{\text {ss }}$ phase on the initial surface ceramics. Although at the end of the SBF test the thickness of the dense CHA layer is almost the same for both ceramics $(35.10 \pm 0.05 \mu \mathrm{m}$ for $31 \mathrm{AC}$ and $35.04 \pm 0.05 \mu \mathrm{m}$ for $31 \mathrm{R})$, the mechanism is different since the $31 \mathrm{AC}$ ceramic has a porous CHA interlayer of $16.10 \pm 0.05 \mu \mathrm{m}$ that the $31 \mathrm{R}$ ceramic does not presents.

Regarding the morphology of the cells growing on the $31 \mathrm{R}$ and $31 \mathrm{AC}$ ceramics, the cells underwent their morphological changes to stabilize the cell-biomaterial interface, and the cells spread and established close contacts with the ceramics, adapting a flattened morphology and showing filopodia anchoring the cells to the bioactive ceramics after $24 \mathrm{~h}$. The cells growing in the presence of $31 \mathrm{R}$ were able to produce small mineral deposits of calcium phosphate both in the extracellular matrix core and in the proximities of the cells (Fig. 9). This effect was also observed with other types of bioactive ceramic. ${ }^{38,39}$ The results obtained for the proliferation and growth of the hASC on the $31 \mathrm{R}$ and $31 \mathrm{AC}$ ceramics provided that after 21 days culture the distribution of cells over the specimens was homogeneous and they were well attached, uniformly colonizing the sample surface. This indicates that the materials developed in this study are biocompatible, with a high colonization and proliferation rate (Fig. 11).

It is recognized that the cell behavior on artificial materials depends on the surface characteristics, such as roughness, improving cell attachment and proliferation. hASC demonstrate significantly higher levels of cell attachment on rough sandblasted surfaces with irregular morphologies than on smooth surfaces. ${ }^{40-42}$ The 31 AC ceramic samples studied in the present work exhibited irregular surface morphology, as shown in Figs. 2A and 4A. Thus, the surface properties of the material can help to promote hASC cell attachment. The inductive effect of the ceramics on hASC adhesion and proliferation should be favored by the release of $\mathrm{Si}$ and $\mathrm{Ca}$ ions into the medium (Fig. 7) and formation of the previously mentioned CHA layer (Figs. 5 and 6). Hence, formation of the CHA layer by release of Si and $\mathrm{Ca}$ ions into the medium stimulates hASC proliferation.

Cell culture does not allow an analysis of possible differences in response resulting from the different major phases present in the samples (single polycrystalline $\mathrm{R}_{\mathrm{Ss}}$ phase or lamellar $\alpha^{\prime}-\mathrm{C}_{2} \mathrm{~S}_{\mathrm{ss}}$ and $\mathrm{A}_{\mathrm{ss}}$ phases). Under culture conditions the levels of viable cell adhesion on crack free specimen surfaces were comparable with other $\mathrm{Si}-\mathrm{CaP}$ surfaces in the same medium. ${ }^{40-44}$

The present results verify that features such as morphology and microstructure can modulate cells responses in vitro, including cellular colonization, proliferation, attachment and surface structure of the forming cells multilayer network. This eutectoid ceramic could serve as a promising platform for regeneration of hard tissue.

\section{Conclusions}

By using the sub-system $\mathrm{Ca}_{2} \mathrm{SiO}_{4}-7 \mathrm{CaOP}_{2} \mathrm{O}_{5} 2 \mathrm{SiO}_{2}$, we have designed and processed two materials with chemical composition of the invariant eutectoid point and different structure (single polycrystalline or lamellae morphology).

A combination of chemical, structural and morphological factors were responsible for the different in vitro behavior of the two materials, both with a common composition. The results confirm that to establish the potential bioactivity in vitro of a material, not only the physiological medium must be properly selected but also the chemical composition, structure and microstructure of the materials must be studied in depth.

The bioactivity and biocompatibility of all these ceramics depended on their microstructure. We cannot tell which of the two materials have improved bioactivity in vitro because both materials have almost the same CHA-like layer thickness at the end of the study. Cell attachment was slightly higher in the case of the $31 \mathrm{AC}$ ceramic, although both ceramics presented the cells' spreading, established close contacts with the substrates, and adapted a flattened morphology with numerous filopodia anchoring the cells to the ceramic surfaces.

By means of processing technology, it is possible to tailor ceramic biomaterials with controlled microstructures in order to improve their osteointegration. 


\section{Acknowledgments}

Part of this work was supported by Ministry of Economy and Competitiveness of Spain (MINECO); contract grant number: MAT2013-48426-C2-2-R. We are very grateful to Dr. N. Vicente for his kind help in the course of the cell analyses.

\section{Appendix A. Supplementary data}

Supplementary data associated with this article can be found, in the online version, at http://dx.doi.org/10.1016/ j.jeurceramsoc.2014.08.039.

\section{References}

1. Hench LL. Bioceramics: from concept to clinic. J Am Ceram Soc 1991;74:1487-510.

2. De Aza PN, De Aza AH, De Aza S. Crystalline bioceramic materials. Bol Soc Esp Ceram Vidrio 2005;44(3):135-45.

3. De Aza PN, De Aza AH, Pena P, De Aza S. Bioactive glasses and glass ceramics materials. Bol Soc Esp Ceram Vidrio 2007;46(2):45-55.

4. Best SM, Porter AE, Thian ES, Huang J. Bioceramics past, present and for the future. J Eur Ceram Soc 2008;28:1319-27.

5. Chevalier J, Gremillard L. Ceramics for medical applications: a picture for the next 20 years. $J$ Eur Ceram Soc 2009;29:1245-55.

6. De Aza PN, Luklinska Z, Anseau MR. bioactivity of diopside ceramic in human parotid saliva. J Biomed Mater Res 2005;73(B(1)):54-60.

7. Carrodeguas RG, De Aza AH, Garcia-Paez I, De Aza S, Pena P. Revisiting the phase-equilibrium diagram of the $\mathrm{Ca}_{3}\left(\mathrm{PO}_{4}\right)_{2}-\mathrm{CaMg}\left(\mathrm{SiO}_{3}\right)_{2}$ system. $J$ Am Ceram Soc 2010;93(2):561-9.

8. Ryu HS, Hong KS, Lee JK, Kim DJ, Lee JH. Magnesia-doped $\mathrm{HA} / \beta \mathrm{TCP}$ ceramics and evaluation of their biocompatibility. Biomaterials 2004;25:393-401.

9. Carlisle EM. Silicon: an essential element for the chick. Science 1972;178:619-21.

10. Carlisle EM. A silicon requirement for normal skull formation in chicks. $J$ Nutr 1980;110:352-9.

11. Carlisle EM. Silicon: a possible factor in bone calcification. Science 1970;167:279-80.

12. Schwarz K, Milne DB. Growth-promoting effects of silicon in rats. Nature 1972;239:333-4.

13. Groves GW. Phase-transformations in dicalcium silicate. J Mater Sci 1983;18(6):1615-24.

14. Chan CJ, Kriven WM, Young JF. Physical stabilization of the betagamma transformation in dicalcium silicate. J Am Ceram Soc 1992;75(6):1621-7.

15. Rodriguez JL, Rodriguez MA, De Aza S, Pena P. Reaction sintering of zircon-dolomite mixtures. J Eur Ceram Soc 2001;21(3):343-54.

16. Vogan JW, Hsu L, Stetson AR. Thermal barrier coatings for thermal insulation and corrosion-resistance in industrial gas-turbine engines. Thin Solid Films 1981;84(1):75-87.

17. Jansen F, Wei XH, Dorfman MR, Peters JA, Nagy DR. Performance of dicalcium silicate coatings in hot-corrosive environment. Surf Coat Technol 2002;149(1):57-61.

18. Smith DK, Majumdar AJ, Ordway F. Re-examination of the polymorphism of dicalcium silicate. J Am Ceram Soc 1961;44(8):405-11.

19. Gou ZG, Chang J, Zhai WY. Preparation and characterization of novel bioactive dicalcium silicate ceramics. J Eur Ceram Soc 2005;25(9):1507-14.

20. Gou ZG, Chang J. Synthesis and in vitro bioactivity of dicalcium silicate powders. J Eur Ceram Soc 2004;24(1):93-9.

21. LeGeros RZ. Calcium phosphate materials in restorative dentistry: a review. Adv Dent Res 1988;2:164-83.

22. Carrodeguas RG, De Aza S. Alpha-tricalcium phosphate: synthesis, properties and biological applications. Acta Biomater 2011;7(10):3536-46.
23. Trömel G. Beiträge zur kenntnis des systems kalziumoxydphosphorpentoxyd, Mitt Kaiser-Wilhelm-Inst Eisenforschg. Düsseldorf 1932; 14:25-34.

24. Welch JH, Gutt JH. High-temperature studies of the system calcium oxidephosphorus pentoxide. J Chem Soc 1961;444:2-4, 4.

25. Bandyopadhyay A, Bernard S, Xue W, Bose S. Calcium phosphate-based resorbable ceramics: influence of $\mathrm{MgO}, \mathrm{ZnO}$, and $\mathrm{SiO}_{2}$ dopants. J Am Ceram Soc 2006;89(9):2675-88.

26. Minarelli-Gaspar AM, Saska S, Carrodeguas RG, De Aza AH, Pena P, De Aza PN, et al. Biological response to wollastonite doped $\alpha$-tricalcium phosphate implants in hard and soft tissues in rats. Key Eng Mater 2009:7-10, 396-98.

27. Mate-Sanchez de Val JE, Calvo-Guirado JL, Delgado-Ruiz RA, RamirezFernandez Ma P, Martinez IM, Granero-Marin JM, et al. New block graft of alpha-TCP with silicon in critical size defects in rabbits: chemical characterization, histological, histomorphometric and micro-CT study. Ceram Int 2012;38:1563-70.

28. Pietak AM, Sayer M. Functional atomic force microscopy investigation of osteopontin affinity for silicon stabilized tricalcium phosphate bioceramic surfaces. Biomaterials 2006;27:3-14.

29. Dorozhkin SV. In vitro mineralization of silicon containing calcium phosphate bioceramics. J Am Ceram Soc 2007;90(1):244-9.

30. Martinez IM, Velasquez PA, De Aza PN. Synthesis and stability of $\alpha$-tricalcium phosphate doped with dicalcium silicate in the system $\mathrm{Ca}_{3}\left(\mathrm{PO}_{4}\right)_{2}-\mathrm{Ca}_{2} \mathrm{SiO}_{4}$. Mater Charact 2010;61:761-7.

31. Martinez IM, Velasquez PA, Meseguer-Olmo L, De Aza PN. Production and study of in vitro behaviour of monolithic $\alpha$-tricalcium phosphate based ceramics in the system $\mathrm{Ca}_{3}\left(\mathrm{PO}_{4}\right)_{2}-\mathrm{Ca}_{2} \mathrm{SiO}_{4}$. Ceram Int 2011;37:2527-35.

32. Velasquez P, Luklinska ZB, Meseguer-Olmo L, Mate-Sanchez de Val JE, Delgado-Ruiz RA, Calvo-Guirado JL, et al. $\alpha$-TCP ceramic doped with dicalcium silicate for bone regeneration applications prepared by powder metallurgy method: in vitro and in vivo studies. $J$ Biomed Mater Res A 2013;101A(7):1943-54.

33. Fix W, Heymann H, Heinke R. Subsolidus relations in the system $2 \mathrm{CaO} \cdot \mathrm{SiO}_{2}-3 \mathrm{CaO} \cdot \mathrm{P}_{2} \mathrm{O}_{5}$. J Am Ceram Soc 1969;52(6):346-7.

34. Martinez IM, Velasquez PA, De Aza PN. The sub-system $\alpha-\mathrm{TCP}_{\mathrm{ss}}-$ Silicocarnotite within the binary system $\mathrm{Ca}_{3}\left(\mathrm{PO}_{4}\right)_{2}-\mathrm{Ca}_{2} \mathrm{SiO}_{4}$. J Am Ceram Soc 2012;95(3):1112-7

35. Rubio V, de la Casa-Lillo MA, De Aza S, De Aza PN. The system $\mathrm{Ca}_{3}\left(\mathrm{PO}_{4}\right)_{2}-\mathrm{Ca}_{2} \mathrm{SiO}_{4}$ : the sub-system $\mathrm{Ca}_{2} \mathrm{SiO}_{4}-7 \mathrm{CaOP}_{2} \mathrm{O}_{5} 2 \mathrm{SiO}_{2}$. J Am Ceram Soc 2011;94(12):4459-62.

36. Eriksson G, Gu P, Blander M, Pelton AD. Critical evaluation and optimisation of the thermodynamic properties and phase diagrams of the $\mathrm{MnO}-\mathrm{SiO}_{2}$ and $\mathrm{CaO}-\mathrm{SiO}_{2}$ systems. Can Metall Q 1994;33:13-21.

37. Kokubo T, Takadama H. How useful is SBF in predicting in vivo bone activity? Biomaterials 2006;27:2907-15.

38. Dubois SG, Floyd EZ, Zvonic S, Kilroy G, Wu X, Carling S, et al. Isolation of human adipose-derived stem cells from biopsies and liposuction specimens. Methods Mol Biol 2008;449:69-79.

39. Zuk PA, Zhu M, Mizuno H, Huang J, Futrell JW, Katz AJ, et al. Multilineage cells from human adipose tissue: implications for cell-based therapies. Tissue Eng 2001;7:211-26.

40. Kieswetter K, Schwartz Z, Hummert TW, Cohran DL, Simpson J, Dean DD, et al. Surface roughness modulates the local production of growth factors and kytokines by osteoblast-like MG-63 cells. J Biomed Mater Res 1996;32:55-63.

41. Ballard JD, Ballard JD, Dell'Acqua-Bellavitis LM, Bizios R, Siegel RW. Nanoparticle-decorated surfaces for the study of cell-protein-substrate interactions. Mater Res Soc Symp Proceed 2005;845:339-44.

42. Müller P, Bulnheim U, Diener A, Luthen F, Teller M, Klinkenberg ED, et al. Calcium phosphate surfaces promote osteogenic differentiation of mesenchymal stem cells. J Cell Mol Med 2008;12:281-91.

43. Bowers KT, Keller JC, Randolph BA, Wick DG, Michaels CM. Optimization of surface micromorphology for enhanced osteoblast responses in vitro. Int J Oral Maxillofac Implants 1992:7302-10.

44. El-Ghannam A, Ducheyne P, Shapiro IM. Effect of serum proteins on osteoblast adhesion to surface-modified bioactive glass and hydroxyapatite. J Orthop Res 1999;17(3):340-5. 